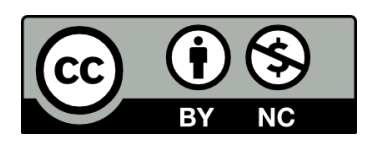

\title{
Montessori Education: Teacher Perceptions of Challenges in Transitioning to Virtual Instruction
}

Catherine M. Scott and Brooke M. Myers, Coastal Carolina University

Keywords: elementary, Montessori, virtual instruction, COVID-19

Abstract: In 2020, Montessori teachers and families across the world had to adjust as schools were closed because of the rapid onset of the COVID-19 pandemic. Those working in the Montessori classroom, which typically favors a hands-on approach and limited use of technology, had to devise new ways to engage with students in the virtuallearning environment. How do teachers perceive that the transition to online learning affected their instruction? This descriptive case study examined the ways in which a school's Lower and Upper Elementary Montessori teachers adjusted their instruction to meet student needs online, as well as the benefits and challenges that the teachers felt they and the students experienced as a result.

Montessori education is recognized for its holistic approach to education; in the Montessori environment, children are provided a sense of control as they engage with materials and progress through the curriculum. The unique features of the Montessori environment allow the child to manipulate and interact with hands-on materials, imitating the concepts taught to them by classmates and instructor until they achieve a level of mastery. Embedded within the Montessori approach are opportunities for students to engage in regulating behaviors; for example, through the Montessori work cycle, children are able to learn to develop a plan of action and enact that plan for getting work done. They are required to test their ideas and adjust their plans as needed. These carefully considered pieces of the curriculum are part of what makes Montessori instruction so different from that of the traditional classroom (American Montessori Society, n.d.).
However, what happens when the Montessori approach is interrupted because of the onset of COVID-19? In 2020, schools across the world were closed because of the rapid onset of the pandemic, causing changes for teachers, families, and students. Those working in the Montessori classroom, which typically favors a hands-on approach and limited use of technology (MacDonald, 2016), had to devise new ways to engage with students in the virtual-learning environment. As a result, we were curious: What concerns do teachers have as they navigate this transition to online instruction in a Montessori classroom? This exploratory case study examined the ways in which a school's Lower and Upper Elementary Montessori teachers adjusted their instruction to meet student needs online, as well as the benefits and challenges they felt they and the students experienced as a result. 


\section{Literature Review}

Because our research focused on Montessori approaches to learning and virtual learning, we provide a literature review of each topic, examining previous research on how the Montessori approach and the ways in which the Montessori approach might change through virtual-program implementation. It was important to determine how use of virtual programs might complement or interfere with key features of the Montessori approach to learning.

\section{Montessori Approach to Learning}

The Montessori classroom provides opportunities for students to engage in a multiage learning environment. Primary classes consist of children aged 3 through 6 years, Lower Elementary serves grades 1 through 3, Upper Elementary serves grades 4 through 6 , and middle school may include grades 7 through 9 . Age groups are strategically designed to align with what Maria Montessori referred to as sensitive periods, times when children undergo developmental milestones and significant learning. These sensitive periods affect children's academic understanding and social growth, which includes learning how to work as a community and collaborate with peers (Lillard, 2016; Zimmerman \& Schunk, 2014).

The aim of the Montessori Method is to support the development of the whole child while promoting independence, responsibility, and an individual who has the utmost self-respect and can rely on their own intrinsic motivation to guide them through decision-making. As Bagby and Sulak (2018) noted, "Children with well-developed executive functioning skills can inhibit negative responses, sustain attention, and use working memory resources effectively" (p. 1). These skills include students' abilities to also manage their time, organize their materials, engage in creative thinking, and focus on goal setting.

Implementing the Montessori Method within the sensitive periods of a child's development encourages educational characteristics such as independence, freedom of choice, development of self-direction, responsibility for one's own actions, and the selfconfidence to blossom (Kayili \& Ari, 2011; Lillard \& Heise, 2006, 2016; Philips-Silver \& Daza, 2018). The Montessori approach is designed to allow these opportunities by providing students choice in their work, using increasingly complex tools as students progress through the curriculum, and minimizing adult intervention in the learning process (Howell et al., 2013).

\section{Virtual Instruction}

Limited research exists that focuses solely on the use of virtual instruction in early elementary classrooms. Virtual instruction, in this case study, refers to the use of full-time, synchronous instruction. A 2016 study from the National Education Policy Center (NEPC) noted that more than half $(51.5 \%)$ of online schools were charter schools and that an average of 305 students were in each of these schools. These demographics are similar to those of the charter school in which our study took place (NEPC, 2016). However, because of the recent onset of COVID-19, no studies are currently available that examine the shifts from in-person to virtual instruction and their effects on students. Anecdotally, some suggest there are concerns in online learning for younger students, who may be more easily distracted and thus need deeper engagement in virtual platforms ( $\mathrm{Li} \&$ Lalani, 2020).

Traditionally, the use of virtual tools, including computers, is limited in the Montessori classroom, instead emphasizing the use of hands-on, concrete objects during instruction (MacDonald, 2016). Previous research indicates that Montessori teachers may struggle to determine how to best fit technology into the Montessori approach (Jones, 2017); however, Montessori teachers also recognize that including technology in their teaching practices may also help students to further explore Montessori concepts (Cifuentes \& Prozesky, 2014; Hubbell, 2003).

Research on best practices in online education (DiPietro et al., 2008) indicates that effective virtual instruction in $\mathrm{K}-12$ settings encourages collaboration and interaction among students, their peers, and the teacher; further, effective virtual teachers build relationships with their students and are able to identify students in crisis or who need additional support. As with traditional, face-to-face instruction, effective virtual educators know their content, use multiple strategies to assess learning, and use instructional strategies that engage students with the content (DiPietro et al., 2008). Similarly, Cavanaugh et al.s (2004) meta-analysis of virtual instruction in K-12 classrooms found that these factors, as well as student characteristics, had a direct impact on student success in virtual instruction. Those characteristics may include a student's self-motivation, organizational skills, and ability to work independently (Cerniglia, 2011), all areas 
developed through the use of Montessori instruction.

With the onset of the pandemic, Murray et al. (2021a) administered a survey to Montessori educators to examine the ways in which the teachers developed and implemented both virtual and hands-on experiences during the pandemic. Of the 222 respondents, $75 \%$ noted that more than half of their students (60\%) were in virtual instruction and that input from administration was limited in terms of support for the transitions to online teaching; only $20 \%$ of participants felt they received moderate amounts or a great deal of support from administration. The majority of teachers engaged in videoconferencing with students as a means of instruction but noted that typical Montessori strategies, such as including choice in assignments and providing access to Montessori materials, were a challenge (Murray et al., 2021a). Further research (Murray et al., 2021b) reaffirmed these difficulties for teachers; in a study of social media and webinar data, the researchers found that teachers were struggling to determine best practices and instructional strategies for a transition to online learning and that the teachers were relying on one another for support and ideas.

Although the American Montessori Society (AMS) has developed some suggestions for teachers on how to develop effective teaching videos to share with students, neither AMS nor Association Montessori Internationale provides teachers extensive information on how to translate the in-person Montessori learning environment to online instruction, nor are there resources to discuss how these transitions affect use of Montessori best practices. Also, limited research is available on how Montessori teachers are navigating these changes to the curriculum. Therefore, this study attempts to fill a gap in the literature by addressing two questions: What concerns do teachers have as they navigate this transition to online instruction in a Montessori classroom? What benefits and challenges do teachers perceive that students have as they transition to online learning?

\section{Theoretical Framework}

The literature on Montessori education and virtual instruction informed this study's theoretical framework. Given our understanding of Montessori practices, we recognize that the curriculum, through its hands-on materials and opportunities for self-direction, enables unique learning opportunities for students. However, these practices may be at odds with what can be accomplished through virtual instruction, particularly when there is little to no support for teachers as they navigate the transition to online instruction. Therefore, we expected to see new challenges for teachers (and students) as they negotiated issues such as student support, accountability, and developing curricular materials in unnavigated territory (see Figure 1).

These expectations guided the coding for our qualitative data analysis, which focused on describing the teachers' perceptions as they negotiated the new learning environment. Using a descriptive lens, we examined qualitative data from interviews and written correspondence to identify key themes in participant responses. A descriptive approach was used for this study as it recognizes that many variables may affect study outcomes, no variables were manipulated, and no interventions were implemented (Creswell, 2014).

\section{Figure 1}

Theoretical Framework

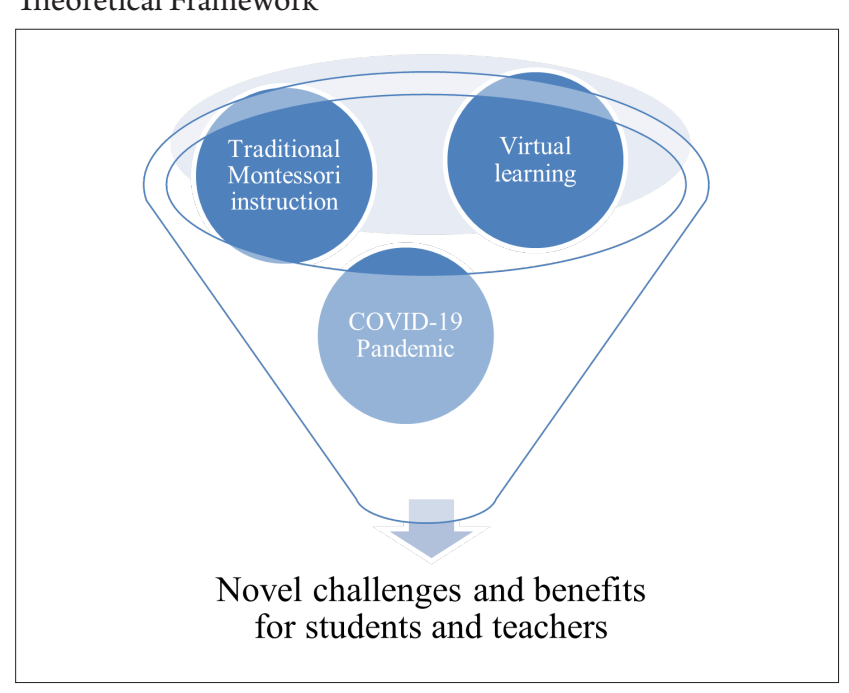

\section{Methodology}

\section{Context}

This case study took place in a public charter school located in the southeastern United States. The school district serves fewer than 9,000 pre-K-12 students and includes 11 elementary schools. The school is the only charter school in the district, which opened in 2012 and serves 236 students in grades 1 through 8 (ages 6-13). Because the school is a charter school, teachers are allowed autonomy in classroom structure and planning as long as they follow Montessori principles. The school is held to the same accountability standards as traditional 
schools across the district. The school follows a 3-year learning cycle with its students: students remain in the same classroom for 3 years.

\section{School Community}

The school district in which the study occurred serves four small towns, but the majority of students reside in the town where the school itself is located. The area is a moderately wealthy community with just under 14,000 residents and an average household income of $\$ 55,500$; the median home value is $\$ 310,000$. The majority of residents are White ( $88.7 \%)$, and the median age is 60 ; only $20 \%$ of households in the area have children.

\section{Participants}

Four teachers from the school participated in the study, two from the Lower Elementary level (grades $1-3$ ) and two from the Upper Elementary level (grades 4-6). All four teachers taught virtually during the study. Information about each participant can be found in Table 1. Institutional review board approval was obtained, and all participants consented to participation.

\section{Data Sources}

Because this is a descriptive study, we relied on information from teacher focus groups and individual teacher interviews to learn how the teachers felt online instruction was affecting the students in their classrooms.

\section{Focus-Group Interview}

A focus-group interview was conducted with three of the four participants via Zoom. The interview was recorded and transcribed. Interview questions were semistructured to allow open-ended responses from participants. Because of scheduling issues, the fourth teacher shared her responses to the interview questions via email, answering follow-up questions also by email. The interview questions are in Appendix A.

\section{Individual Interviews}

Individual interviews occurred with one Lower Elementary teacher ("Jane") and one Upper Elementary teacher ("Kate") to discuss the lessons taught, student outcomes, and their perceptions of students' abilities to self-regulate in the lessons. These interviews were not recorded; we took detailed notes through each interview.

\section{Data Analysis}

Interview data and email responses were analyzed by segmenting the responses into coding categories. These categories were developed by using common themes found across each participant's responses (Yin, 2003). Data were first coded independently by each researcher, identifying tentative codes for categories that repeatedly came up in conversation. Next, the researchers met to discuss findings and revise codes as needed. At this time, the reviewers narrowed down the coding categories to hone in on key points (see Table 2 for coding schemes). After the set of themes was agreed upon, the researchers

Table 1

Teacher Demographic Information

\begin{tabular}{llccl}
\hline \multicolumn{1}{c}{ Teacher } & \multicolumn{1}{c}{ Grade level } & $\begin{array}{c}\text { Years at } \\
\text { Montessori } \\
\text { school }\end{array}$ & $\begin{array}{l}\text { Total years' } \\
\text { experience }\end{array}$ & \multicolumn{1}{c}{ Certifications } \\
\hline Jane Smith & $\begin{array}{l}\text { Lower Elementary } \\
(1-3)\end{array}$ & 6 & 27 & $\begin{array}{l}\text { Elementary I Montessori; Grades } \\
\text { PreK-3 (state); } \\
\text { Gifted and Talented }\end{array}$ \\
Deb Thomas & $\begin{array}{l}\text { Lower Elementary } \\
(1-3)\end{array}$ & 5 & 20 & $\begin{array}{l}\text { Elementary I Montessori; Grades } \\
\text { PreK-3 (state) }\end{array}$ \\
Chelsea Jones & $\begin{array}{l}\text { Upper Elementary } \\
(4-6)\end{array}$ & 10 & 13 & $\begin{array}{l}\text { Elementary II Montessori; Grades 2-6 } \\
\text { (state); }\end{array}$ \\
Kate Allen & $\begin{array}{l}\text { Upper Elementary } \\
(4-6)\end{array}$ & 10 & 31 & $\begin{array}{l}\text { Gifted and Talented } \\
\text { Elementary II Montessori; Grades 2-6 } \\
\text { (state); }\end{array}$ \\
\hline
\end{tabular}

*All names are pseudonyms. 
Table 2

Coding Schemes for Data Analysis

\begin{tabular}{|c|c|c|}
\hline Initial code & Examples to support & Final code \\
\hline Building community & $\begin{array}{l}\text { What do we do so kids can get to know } \\
\text { each other? } \\
\text { How do we create a place for families to } \\
\text { feel supported? }\end{array}$ & Supporting students \\
\hline Coping skills/dealing with stress & $\begin{array}{l}\text { Harder to see the kids on screen; how do } \\
\text { we know if they are upset? } \\
\text { Watching for indicators of frustration } \\
\text { while online }\end{array}$ & \\
\hline $\begin{array}{l}\text { Developing student-teacher } \\
\text { relationships }\end{array}$ & $\begin{array}{l}\text { Harder to get to know new students } \\
\text { online } \\
\text { Fortunate to have had } 2 / 3 \text { of the students } \\
\text { for previous year or } 2 \text { because of learning } \\
\text { cycle }\end{array}$ & \\
\hline Parental expectations & $\begin{array}{l}\text { Comparing their own schooling } \\
\text { experience to what their children are } \\
\text { experiencing } \\
\text { Worrying about what their children are } \\
\text { missing } \\
\text { Balancing the amount of support } \\
\text { provided (doing too much for their child } \\
\text { versus not being involved at all) }\end{array}$ & Resiliency \\
\hline COVID-19 restrictions & $\begin{array}{l}\text { Concerns about local mandates for } \\
\text { plexiglass, masks, distancing } \\
\text { Parents and teachers worried about sick } \\
\text { kids at school }\end{array}$ & \\
\hline $\begin{array}{l}\text { Following through with school } \\
\text { responsibilities }\end{array}$ & $\begin{array}{l}\text { Student response guides how we react to } \\
\text { missing work or late assignments. } \\
\text { Kids know they have to be responsible } \\
\text { and get it done. } \\
\text { Hard to deal with issues like parents } \\
\text { taking kids out of school for other } \\
\text { activities, so work is not done }\end{array}$ & Student accountability \\
\hline Home distractions & $\begin{array}{l}\text { Students can go play video games during } \\
\text { the breaks (and sometimes not come } \\
\text { back on time). } \\
\text { There are distractions at home that do not } \\
\text { exist at school. }\end{array}$ & \\
\hline $\begin{array}{l}\text { Family demands (work-home } \\
\text { balance) }\end{array}$ & $\begin{array}{l}\text { Parents have to work and not be home for } \\
\text { kids. } \\
\text { Parents struggle with knowing how to } \\
\text { support kids with school, now that they } \\
\text { are home all day. }\end{array}$ & Environmental influences \\
\hline Student support at home & $\begin{array}{l}\text { Some students have parents with them all } \\
\text { day, and others do not. We have to know } \\
\text { to meet them where they are at. }\end{array}$ & \\
\hline Home distractions & $\begin{array}{l}\text { Concern about video games, siblings, and } \\
\text { other interruptions. }\end{array}$ & \\
\hline
\end{tabular}


then rewatched the focus-group interview video and reviewed its transcript, rechecking the emailed correspondence to confirm the findings.

\section{Methods}

When examining teacher responses in the focusgroup interview, we saw that four major themes emerged, each of which is described in greater detail below: student support, resiliency, student accountability, and environmental influences.

\section{Student Support}

All four teachers noted that their goals were to establish relationships with the students and support them in their virtual classrooms. This occurred through a variety of formats; one teacher held a Wednesday lunch with her students so that they could log on and eat lunch together. The other three teachers noted that they also provided support at nonacademic times so that students could log on, ask questions, and spend time together. As Kate shared, "Once a week we have our students come together as a cluster of kids where they can share their cats and show their gardens. Whatever they feel they need to do" (K. Allen, personal communication, March 8, $2021)^{1}$. These actions aligned with findings from Murray et al. (2021a, 2021b); teachers in that study shared that they had engaged in lunches, book groups, and virtual social times with students to provide opportunities for collaboration and social engagement.

When asked if they felt that their approaches were effective, the teachers agreed that, for the most part, they seemed to help students build a sense of community in a virtual setting. One teacher commented that students sometimes lingered online after class to talk with her and that they sometimes shared information they never would have shared in person. However, there were some concerns, particularly with dealing with students who would become frustrated by content difficulties or technology issues. Although the teachers appreciated how they were able to allow a student to log off to gather himself or herself and rejoin the group when ready, they also recognized that students might be showing signs of frustration (e.g., watering eyes) that they may miss when looking at 24 faces on a computer screen. One teacher shared that she tried to watch body language with two

${ }^{1}$ All teacher names are pseudonyms. students whom she knew had difficulties with executive functioning. She explained that her goal was to provide those students with other moments, such as free time to log in and just talk, to help them feel more comfortable sharing their frustration in class, allowing everyone to work through it together.

\section{Resiliency}

A major concern and topic of conversation among many adults is how the COVID generation of children will bounce back after their extended absence from an in-person classroom setting. (Bauerlein, 2021; Richards, 2020). How will students rebound after they miss so many opportunities for growth and development in school? While it may be surprising, a commonality among all four teachers was that the majority of children in their classes seemed unharmed. As "Chelsea"

explained,

For me as the adult, I know how much we're missing because we're virtual. Because I know I've been missing that [the building of student-teacher relationships] a lot. But in the students' minds we still have a close relationship. We are still making the impact socially and emotionally; it's just not the one teachers are used to. The students are content with the friendships and relationships they have developed. (C. Jones, personal communication, March 8, 2021)

The other party that typically has concerns regarding resiliency is the parents and families of students. Because most families had been through the traditional education system, they were likely comparing the experiences they had had in school to the virtual experience their children were having. When imagining the educational needs of their children before the pandemic, families likely pictured the typical general education classroom. The reality of the situation was that, regardless of whether the children were in school or learning virtually, their education was different than in pre-COVID times. Jane said, 'Unfortunately, in-person is far from 'normal' right now, so they're not really missing what they think they might be missing" (J. Smith, personal communication, March 8, 2021). Students attending in-person school were wearing masks and socially distanced, in a scenario unlike that of prior school years. Following district guidelines, group work was extremely limited, and students sat within plexiglass barriers and were not 
allowed to mingle with other grade-level classes. Because of these restrictions, Jane argued that

the needs of students with existing social and emotional regulation skills might be better met in the "in-person" option, but maybe not. Is it better to be in a tiny box on a screen or in a tiny plastic box in the classroom? I really don't know. (C. Smith, personal communication, March $8,2021)$

Both Jane and Kate shared examples of the lessons that their students were completing at home and that allowed opportunities for movement, STEM (e.g., building a robot from recycled goods and writing about what the robot did), and hands-on mathematics, which could not be completed in the school building because of COVID-based safety restrictions. Thus, while children were missing some of the typical in-person educational opportunities that their families had experienced, their virtual environment was perhaps less restrictive than the in-person options available.

\section{Student Accountability}

Working with students on developing personal accountability was a common concern for participants. Similar to the teachers in Murray et al.s study (2021b), our teachers worked on ways to encourage selfdiscipline and independent work among their students. Chelsea said, "We have kids who are relying on us to give them skills to be self-reliant" (C. Jones, personal communication, March 8, 2021). The teachers shared that many times student frustration came not from the content but from students not turning in their work or from choosing activities such as playing video games during class break times (when they should be completing independent assignments). Chelsea further explained:

Once the excuses go, the students we are meeting with are the ones who decided to play video games during the school day and didn't come to class. Then what we are combating ... are things that the students have messed up for themselves. (C. Jones, personal communication, March 8, 2021)

For both Chelsea and Kate, student accountability appeared to be a greater issue, perhaps because these teachers were working with students in Upper Elementary grades.
All of the teachers indicated that it was generally evident when students had support at home to aid them in personal accountability and when they did not. Differences in student responses (e.g., "I didn't do the work because my mom was working and could not help me" versus "I didn't do the work because I was playing video games") were easier for the teacher to detect through how students responded when asked about absences or missing assignments. Across both age bands, student concerns about missing work were exacerbated by parental decisions to have the students miss school, as when booking a doctor's appointment in the middle of the day. These situations appeared to upset students more than the times when their absences were their own fault (as when playing video games) because these absences were beyond students' control. However, regardless of age group, the teachers agreed that students recognized the need to be accountable for their own actions.

\section{Environmental Influences}

When discussing frustrations associated with the virtual-learning platform, all four teachers mentioned one specific idea: influences in a student's home environment affect the way they develop, and these influences become much more prevalent in the virtual environment. As educators in an online education system, the teachers can only interpret what is seen on camera. Chelsea explained, "There's no way to control what's happening at home. There are ways to help and assist, but ultimately everyone runs their homes the way they think is best" (C. Jones, personal communication, March 8, 2021). Because students' home lives and school days had merged, their rules and ideas about education had as well. Families were having to balance work, family life, and their child's education at the same time. For some, this meant that the child was unsupervised at home during the school day, while others had the resources to be home with their kids. The teachers noted that they tried to stay aware of these circumstances so that they could determine the best means to reach the students.

On the other hand, some children appeared to be thriving because of their new environmental influences. As "Deb," a Lower Elementary teacher, stated,

The kids who are not getting the support at all are being impacted. The kids who are getting the support at home are being impacted, but in a positive way. It really depends on what happens when the students click "end 
meeting." (D. Thomas, personal communication, March 8, 2021)

Similar to Murray et al., (2021a), our teachers found that parents could serve as a great source of support for the children in their classrooms, so they wanted to further opportunities to help parents engage with their children. They found themselves providing more educational resources to help families build their child's emotional and organizational skills through virtual learning, rather than having to focus on content alone. For example, one teacher provided articles and tutorials to explain to families that "this is what it looks like to talk to an upset child, this is what it looks like to talk to a frustrated child, these are things you can do to help your child practice independence" (D. Thomas, personal communication, March 8, 2021). Jane also shared examples of the work that she assigned students; rather than assign only projects that they had to complete on their own, the students in her class were encouraged to work with a sibling or family member to complete tasks, such as making the longest paper chain using one sheet of paper. She noted that the kids were excited to involve others in their activities and that she was fine with family participation if it helped keep the students engaged and involved (J. Smith, personal communication, March 8, 2021). When families were provided the resources to engage in and support their child's social and emotional development, students were able to benefit.

\section{Discussion}

While this study used a small sample size and focused on teacher perceptions in only four classrooms and therefore cannot be generalized across all learning situations, the findings highlight some key themes for Montessori teachers working in the virtual environment. In many ways, virtual learning did not seem to affect some aspects of the learning experience for students. Students were still held accountable for completing their work and accepting responsibility for their work. They also displayed resiliency in handling changes to the learning environment: although the classroom space no longer followed the traditional model, the teachers perceived that, unlike themselves, the students were largely unaffected by the changes. It should be noted that some of the students' ease with the change in the learning environment may be because the older students already had a sense of community in the classroom, having known the teacher and been in in-person instruction with them for a year or more before the school closures.

The teachers shared that there were issues and concerns with aiding students that would be handled differently in an in-person setting. One concern for teachers was the difficulty in recognizing signs of frustration for all students in the virtual setting; it could be difficult to see on the screen when students were getting upset. Also, the types of distractions that students dealt with at home (e.g., video games on break time) presented new challenges for teachers to handle as they tried to engage students in their work. Finally, more time was needed to support parents as they helped their children navigate academic, social, and emotional challenges than was normally required in an in-class setting, where teachers would be spending time with the students to work on these issues.

Each of these issues brings new implications for those working in the virtual-learning environment as they work with students. It will be important, moving forward, for teachers to continue to foster social and emotional regulation skills in students. Teachers should not only continue to provide the supports they developed in their virtual classroom, but they also should consider ways to ensure accessibility for all students. For example, it may be necessary to provide opportunities for students to make up classroom time that may have been lost because of environmental factors. Creating time-management plans for students who may be easily deterred from their school work or sending out weekly check-in surveys to gauge how students are feeling may help teachers gain more insights into students' emotional well-being than having to guess through a screen.

For teachers returning to the classroom after virtual instruction, it is important to consider how the teachers will support students and their families as everyone readjusts to in-class instruction. Teachers may find that more time is needed to provide students emotional support or skills for dealing with frustration that may not have been visible on screen. There may also be challenges as students transition from what they perceive as more freedom working at home to a more structured classroom environment, requiring additional scaffolding support from the teacher.

Finally, although children need all of these supports, it is important to keep in mind how much families influence their child's education. Teachers may need to 
provide opportunities for families to become more involved in their students' learning, especially in the virtual environment. Given that Montessori virtual learning is a new experience for all, parents may need additional supports in learning how their child develops and how to support this learning at home, for both those with children in virtual instruction and those transitioning to face-to-face instruction.

Most importantly, further research must be done on the use of virtual instruction in elementary education environments, particularly Montessori environments, given the dearth of research in this area. Such research may aid teachers in learning best practices for their work and may also aid those working in teacher education as they help teachers and students navigate this new terrain.

\section{Author Information}

Catherine M. Scott is an associate professor of education at Coastal Carolina University and can be reached at cscott1@coastal.edu.

Brooke M. Myers is an early childhood education major at Coastal Carolina University and can be reached at bmmyers1@coastal.edu.

\section{References}

American Montessori Society. (n.d.). Why choose Montessori? https://amshq.org/Families/WhyChoose-Montessori

Bagby, J., \& Sulak, T. (2018). Montessori and executive function. Montessori Life, 30(1), 15. https://www.proquest.com/openview/ efof6f $4793 \mathrm{c} 8 \mathrm{~b} 636935 \mathrm{e} 27 \mathrm{~b} 52 \mathrm{ea} 27 \mathrm{~b} 0 \mathrm{f}$

Bauerlein, V. (2021, May 9). Remote kindergarten during Covid-19 could "impact this generation of kids for their lifetime." The Wall Street Journal. https://www. wsj.com/articles/remote-kindergarten-during-covid19-could-impact-this-generation-of-kids-for-theirlifetime-11620552653

Cavanaugh, C., Gillan, K. J., Kromrey, J., Hess, M., \& Blomeyer, R. (2004). The effects of distance education on K-12 student outcomes: A meta-analysis. https:// files.eric.ed.gov/fulltext/ED489533.pdf

Cerniglia, E. G. (2011). Modeling best practice through online learning: Building relationships. Young Children, 66(3), 54-56, 58-59.
Cifuentes, L., \& Prozesky, K. (2014). The Montessori approach to integrating technology. Problemy Wczesnej Edukacji, 24(1), 29-38. https://tinyurl. com/9bkukcdw

Creswell, J. (2014). Research design: Qualitative, quantitative, and mixed methods approaches. Sage Publications.

DiPietro, M., Ferdig, R. E., Black, E. W., \& Preston, M. (2008). Best practices in teaching K-12 online: Lessons learned from Michigan Virtual School teachers. Journal of Interactive Online Learning, 7(1), 10-35. https://iols.gmu.edu/assets/761/Article2e. pdf

Howell, L., Sulak, T. N., Bagby, J., Diaz, C., \& Thompson, L. W. (2013). Preparation for life: How the Montessori classroom facilitates the development of executive functioning skills. Montessori Life, 25(1), 14-18. http://www.childreninc.org/wp-content/ uploads/2013/01/Preparation-for-Life.pdf

Hubbell, E. R. (2003). Integrating technology into the Montessori elementary classroom. Montessori Life, 15(2), 40-41.

Jones, S. J. (2017). Technology in the Montessori classroom: Teachers' beliefs and technology use. Journal of Montessori Research, 3(1), 16-29. https:// doi.org/10.17161/jomr.v3i1.6458

Kayili, G., \& Ari, R. (2011). Examination of the effects of the Montessori Method on preschool children's readiness to primary education (EJ962690). ERIC. Educational Sciences: Theory and Practice, 11(4), 2104-2109. https://files.eric.ed.gov/fulltext/ EJ962690.pdf

Li, C., \& Lalani, F. (2020, April 29). The COVID-19 pandemic has changed education forever. This is how. World Economic Forum. https://www.weforum.org/ agenda $/ 2020 / 04 /$ coronavirus-education-globalcovid19-online-digital-learning/

Lillard, A. S. (2016). Montessori: The science behind the genius (3rd ed.) Oxford University Press.

Lillard, A. S., \& Heise, M. J. (2006). The early years: Evaluating Montessori education. Science, 313(5795), 1893-1894. https://doi.org/10.1126/ science. 1132362

Lillard, A. S., \& Heise, M. J. (2016). An intervention study: Removing supplemented materials from Montessori classrooms associated with better child outcomes. Journal of Montessori Research, 2(1), 16-26. https://doi.org/10.17161/jomr.v2i1.5678 
MacDonald, G. (2016). Technology in the Montessori classroom: Benefits, hazards, and preparation for life (EJ1110230). ERIC. The NAMTA Journal, 41(2), 99-107. https://files.eric.ed.gov/fulltext/ EJ1112230.pdf

Murray, A. K., Brown, K. E., \& Barton, P. (2021a). Montessori education at a distance, part 1: A survey of Montessori educators' responses to a global pandemic. Journal of Montessori Research, 7(1), 1-29. https://doi.org/10.17161/jomr.v7i1.15122

Murray, A. K., Brown, K. E., \& Barton, P. (2021b). Montessori education at a distance, part 2: A mixedmethods examination of Montessori educators' responses to a global pandemic. Journal of Montessori Research, 7(1), 31-50. https://doi.org/10.17161/ jomr.v7i1.151223

National Education Policy Center. (2016). Virtual schools report 2016. https://files.eric.ed.gov/fulltext/ ED574701.pdf

Philips-Silver, J., \& Daza, M. T. (2018). Cognitive control at age 3: Evaluating executive functions in an equitable Montessori preschool. Frontiers in Psychology, 3(106). https://doi.org/10.3389/feduc.2018.00106

Richards, E. (2020, December 17). Students are falling behind in online school. Where's the COVID-19 'disaster plan' to catch them up? USA Today. https://www.usatoday.com/in-depth/news/education $/ 2020 / 12 / 13 /$ covid-online-school-tutoringplan/6334907002/

Yin, R. L. (2003). Case study research: Design and methods. Sage Publications.

Zimmerman, B. J., \& Schunk, D. H. (Eds.). (2014). Educational psychology: A century of contributions. Routledge. 


\section{Appendix A}

1. What strategies if any have you implemented to help your students deal with frustrations from home?

2. Do you see signs that your students are becoming overwhelmed often due to the online platform?

a. How frequent are these signs?

b. What do they look like?

c. Have you seen a difference in the amount from the start of online learning to now?

3. Do you feel your students are able to self-regulate their emotions through the online platform?

4. How do you feel like the online platform has impacted students with delays in social and emotional regulation skills?

5. How are you promoting the development of social and emotional skills in your classroom?

6. Is your approach different online versus in class? 